\title{
Correlation of prostate specific antigen level with histopathological findings in patients with prostatic disease
}

\author{
Shetty $\mathbf{P}^{1}$, Singh B.M.K ${ }^{2}$, Shetty $\mathbf{T}^{3}$, Bishnu $\mathbf{A}^{4}$ \\ ${ }^{1}$ Dr. Panna Shetty, Department of Pathology, Melaka Manipal Medical College, ${ }^{2}$ Dr Brij Mohan Kumar Singh, \\ Department of Immunohematology \& Blood Transfusion, Kasturba Medical College, ${ }^{3}$ Dr. Tanvi Shetty, Department of \\ Pathology, Melaka Manipal Medical College, ${ }^{4}$ Dr. Arijit Bishnu, Department of Pathology, Melaka Manipal Medical \\ College, all authors are affiliated with Manipal Campus, Manipal University.
}

Address for Correspondence: Dr. Panna Shetty, Department of Pathology, Melaka Manipal Medical College, Manipal Campus, Manipal University, India. E-mail- pannapshetty@gmail.com

\begin{abstract}
Background: Carcinoma of prostate is one of the common tumors of old age in men. Although there is great apprehension in these patients when they are associated with even mild increase in the prostate specific antigen level (PSA) which can be seen in various benign lesions of prostate. With digital rectal examination (DRE), prostate specific antigen (PSA) remains a major screening tool for early detection of prostate cancer. Materials and method: The study includes 150 cases who presented clinically as prostatic lesions and in whom the PSA levels and tissue biopsy was available and was further correlated among spectrum of prostatic disease. Results: All cases with abnormal DRE were turn out to be malignant lesion on biopsy and was found that the cut off of PSA level for malignancy was $19.5 \mathrm{ng} / \mathrm{ml}$. The median PSA levels for benign prostatic hyperplasia (BPH), prostatitis, prostate intraepithelial neoplasia (PIN) and adenocarcinoma is $5 \mathrm{ng} / \mathrm{ml}, 10 \mathrm{ng} / \mathrm{ml}, 14 \mathrm{ng} / \mathrm{ml}$ and $81 \mathrm{ng} / \mathrm{ml}$ respectively. Statistically there was no significant difference of the PSA levels between low grade prostate intraepithelial neoplasm and high grade. Conclusion: In Benign prostatic lesion, PSA level ranges between 0 to $4.0 \mathrm{ng} / \mathrm{ml}$. The cut off value of $19.5 \mathrm{ng} / \mathrm{ml}$ of PSA is most sensitive and specific for the detection of malignant lesion in the prostate. In addition to elevated level of more than 4.0ng/ml and abnormal DRE with TURP biopsy is most useful and accurate diagnostic method for prostatic lesions. All raised PSA levels cases were not malignant thus it is required to use this biochemical marker judiciously to minimize the apprehension among these patients.
\end{abstract}

Keywords: Prostate, Prostate intra-epithelial neoplasm, Prostate specific antigen, Digital rectal examination

\section{Introduction}

The incidence of prostate cancer is rising worldwide as a consequence of transition of world adult population into elderly population resulting in a great apprehension in patients as well as clinicians if they encounter increased prostate specific antigen (PSA) levels.

This is attributed to the improvement of health services, and more importantly understanding the sensitivity and specificity of PSA levels in diagnosing various prostate diseases with the help of prostate specific antigen (PSA) testing. The rationale for screening is the detection of early disease (organ confined) which is amenable to cure $[1,2]$.

Manuscript received: $16^{\text {th }}$ October 2016

Reviewed: $28^{\text {th }}$ October 2016

Author Corrected: $11^{\text {th }}$ November 2016

Accepted for Publication: $21^{\text {st }}$ November 2016

\section{Material and Method}

A total of 150 cases who presented with prostatic disease and in those tissue biopsies with serum PSA levels were assessed, were included in this study which were done in the Department of Pathology, Kasturba Hospital, Manipal from January 2014 to January 2016. Out of total 150 cases, 108 cases were from transurethral resection specimen, 39 cases of needle biopsies, two cases of trans-urethral resection with deroofing and one case of total prostatectomy. Relevant clinical and radiological investigations were collected from case files with the intention to observe the usefulness of PSA levels in various prostatic diseases including prostatic adenocarcinoma. Cases with only tissue biopsy or with only PSA levels were excluded. 


\section{Results}

Linear correlation of disease in prostate was seen in various age groups. With the advancement of the age the transition of the disease was seen from most benign lesion to more aggressive malignant disease (Table1).The presenting complaints were very widely spread and duration of these complaints ranged from as less as one week to a long duration of two years. There was no significant difference found between the mode of presentation of benign and malignant disease. Majority $(73 \%)$ of the patients presented with obstructive lower urinary tract symptoms which included difficulty in micturition, burning micturition, nocturia and increased frequency of micturition. Digital rectal examination (DRE) in combination with PSA can help in the detection of various prostatic lesions. All with abnormal findings on DRE were grouped under suspicious and were further confirmed on histology (Table 2). It was also noted that most of the cases with suspicious on DRE turned out to be adenocarcinoma on histo-morphological examination.

Table-1: Distribution of cases in different age groups $(n=150)$.

\begin{tabular}{|c|c|c|c|c|c|}
\hline Age & BPH & PROSTATITIS & PIN & ADENOCARCINOMA & TOTAL \\
\hline $40-50$ & $2(28.6 \%)$ & $3(42.9 \%)$ & $2(28.6 \%)$ & 0 & 7 \\
\hline $51-60$ & $18(48.6 \%)$ & $10(27 \%)$ & $3(8.1 \%)$ & $6(16.2 \%)$ & 37 \\
\hline $61-70$ & $15(30.6 \%)$ & $16(32.7 \%)$ & $8(16.3 \%)$ & $10(20.4 \%)$ & 49 \\
\hline $71-80$ & $17(38.6 \%)$ & $14(31.8 \%)$ & $7(5.9 \%)$ & $6(13.6 \%)$ & 44 \\
\hline$>80$ & $3(23.1 \%)$ & $2(15.4 \%)$ & $3(23.1 \%)$ & $5(38.5 \%)$ & 13 \\
\hline Total & $\mathbf{5 5}$ & $\mathbf{4 5}$ & $\mathbf{2 3}$ & $\mathbf{2 7}$ & $\mathbf{1 5 0}$ \\
\hline
\end{tabular}

After evaluating various prostatic lesions and comparing them with the PSA levels we found that $100 \%$ of the cases with PSA levels of more than $100 \mathrm{ng} / \mathrm{ml}$ has shown various grades of adenocarcinoma. Maximum variability of PSA levels was seen in cases of benign prostatic hyperplasia (BPH) as compared to inflammation and in-situ neoplasm. (Table3) Also we found median and interquartile range of various lesions in the prostate when we correlated histological diagnosis with PSA levels. (Table 4)

In case of prostatitis, majority of the cases had a PSA value in the range of $4-10 \mathrm{ng} / \mathrm{ml}$. The PSA levels were higher in acute prostatitis when compared to chronic prostatitis but statistically there was no significant difference between the two (Table 5). Among prostate intraepithelial neoplasm (PIN) majority of the cases were associated with benign prostatic hyperplasia and also prostatic inflammation. There was only one case which showed exclusively high grade PIN. Also two cases of adenocarcinoma had high grade PIN as an associated lesion. Among the two types of PIN, maximum level of PSA was seen in low grade PIN which had associated BPH and acute prostatitis. Statistically there was no significant difference between the PSA values in low grade and high grade PIN.

Adenocarcinoma was graded according to Gleason's scoring system. Tumors with a Gleason's score of 5 to 7 were considered as moderately differentiated and with a score of 8 to 10 were considered as poorly differentiated. There were no cases with a score of 2 to 4 which are well differentiated tumors. Moderately differentiated tumors had PSA levels above $10 \mathrm{ng} / \mathrm{ml}$ but less than $100 \mathrm{ng} / \mathrm{ml}$. In case of poorly differentiated tumors 9 of total 22 cases had PSA levels above $100 \mathrm{ng} / \mathrm{ml}$. Hence the values were higher in poorly differentiated tumors (Table 6).

Table-2: Cases with suspicious DRE having adenocarcinoma.

\begin{tabular}{|c|c|c|}
\hline Age range & DRE Suspicious & Adenocarcinoma \\
\hline $40-50$ & 0 & 0 \\
\hline $51-60$ & 9 & 6 \\
\hline $61-70$ & 10 & 10 \\
\hline $71-80$ & 9 & 6 \\
\hline$>80$ & 6 & 5 \\
\hline TOTAL & 34 & 27 \\
\hline
\end{tabular}




\section{Research Article}

We also calculated the sensitivity and specificity of PSA to detect malignancy at different cut off points. The serum PSA has a good sensitivity and specificity at a cut off value of $19.5 \mathrm{ng} / \mathrm{ml}$, with a sensitivity of 96.3 and specificity of 86.2 seen in this study. It was found that cases with a PSA level above $19.5 \mathrm{ng} / \mathrm{ml}$ were more of malignant lesions compared to benign (Table 7). The sensitivity, specificity, positive predictive value and negative predictive value at a cut off of $19.5 \mathrm{ng} / \mathrm{ml}$ were $96.3,86.18,60.47$ and 99.07 respectively.

Table-3: Distribution of different PSA range in various prostatic lesions.

\begin{tabular}{|c|c|c|c|c|c|}
\hline \multirow{2}{*}{$\begin{array}{c}\text { PSA range } \\
(\mathrm{ng} / \mathrm{ml})\end{array}$} & \multicolumn{4}{|c|}{ Histopathology Diagnosis of prostatic lesions } & \multirow[b]{2}{*}{ TOTAL } \\
\hline & BPH & PROSTATITIS & PIN & ADENOCARCINOMA & \\
\hline $0-4$ & 22 & 4 & 4 & 0 & 30 \\
\hline $4.01-10$ & 25 & 19 & 4 & 0 & 48 \\
\hline $10.01-20$ & 4 & 16 & 8 & 2 & 30 \\
\hline $20.01-100$ & 4 & 6 & 7 & 16 & 33 \\
\hline$>100$ & 0 & 0 & 0 & 9 & 9 \\
\hline
\end{tabular}

Table-4: Histopathological diagnosis with PSA level.

\begin{tabular}{|c|c|c|c|c|c|}
\cline { 3 - 6 } & \multicolumn{5}{c|}{ PSA (ng/ml) } \\
\hline \multicolumn{2}{|c|}{ Cases } & Minimum & Maximum & Median & IQR(interquartile range) \\
\hline BPH & $\mathrm{N}$ & & & & \\
\hline ADENOCARCINOMA & 55 & 0.4 & 46 & 5 & 97 \\
\hline PIN & 27 & 10 & 1525 & 81 & 20 \\
\hline PROSTATITIS & 23 & 0.03 & 58 & 14 & 9 \\
\hline
\end{tabular}

Table-5: Correlation of PSA with prostatitis and PIN.

\begin{tabular}{|c|c|c|c|c|c|}
\cline { 2 - 6 } \multicolumn{1}{c|}{} & & \multicolumn{3}{c|}{ PSA ( ng/ml ) } & p value \\
\hline & $\mathbf{n}$ & Minimum & Maximum & 11 & \multirow{2}{*}{0.079} \\
\hline Acute prostatitis & 13 & 3 & 90 & 8 & \\
\hline Chronic prostatitis & 32 & 4 & 58.3 & 14.6 & \multirow{2}{*}{0.245} \\
\hline Low grade PIN & 15 & 0.03 & 23.8 & 15.9 & \\
\hline High grade PIN & 08 & 2.8 & & & \\
\end{tabular}

Table- 6: PSA values in adenocarcinoma of different grade.

\begin{tabular}{|c|c|c|c|c|}
\cline { 2 - 5 } \multicolumn{1}{c|}{} & \multicolumn{4}{c|}{ Range of PSA ( ng/ml) } \\
\hline Adenocarcinoma & $10.01-20$ & $20.01-100$ & $>100$ & Total \\
\hline $\begin{array}{c}\text { Moderately } \\
\text { differentiated }\end{array}$ & 1 & 4 & 0 & 5 \\
\hline Poorly differentiated & 1 & 12 & 9 & 22 \\
\hline Total & 2 & 16 & 9 & 27 \\
\hline
\end{tabular}

Table-7: Cases of adenocarcinoma detected at a PSA cut off point of 19.5ng/ml.

\begin{tabular}{|c|c|c|c|}
\hline PSA (ng/ml) & $\begin{array}{c}\text { Benign } \\
\text { lesions }\end{array}$ & Adenocarcinoma & Total \\
\hline$<19.5$ & 106 & 1 & 107 \\
$\geq 19.5$ & 17 & 26 & 43 \\
\hline Total & 123 & 27 & 150 \\
\hline
\end{tabular}




\section{Discussion}

Prostate specific antigen (PSA) is exclusively produced by the epithelial cells lining the prostatic acini and ducts of prostatic tissue. This high specificity of PSA for prostate tissue has made it a preferred serum marker for carcinoma prostate. However, PSA is specific for prostate tissue but not for prostate cancer. The clinically applicable reference values of PSA is $0-4.0 \mathrm{ng} / \mathrm{mL}[3,4,5]$ but even within the normal range of PSA a minimal risk of cancer does exist [4]. Intermediate values that are from $4.0 \mathrm{ng} / \mathrm{ml}$ to $10.0 \mathrm{ng} / \mathrm{mL}$ could be seen in patients with BPH, prostatitis, PIN and Prostatic cancer.

Majority of the patients were in the age group of 61 to 70 years. This is comparable to studies done by Jasani et al, [5] Lakhey M et al, [4] and Goswami et al [6] who reported similar age of presentation. Around $73 \%$ of the patients in this study presented with obstructive urinary symptoms which was similar to the studies done by FC et al, [7] Cruz J et al [8].

Among all cases, we had $36.6 \%$ with BPH, $30 \%$ prostatitis, $15.3 \%$ of PIN and $18 \%$ were adenocarcinoma. DP Murthy et al [9] had the similar findings, in which majority of the cases were of nodular hyperplasia, few of which were associated with prostatitis. In another study by Jasani et al, [5] 56\% cases were of BPH, but the second most common lesion was adenocarcinoma in contrast to our study in which it was prostatitis.

If we look at the age of presentation of various prostatic lesions we found that BPH usually has its peak between 51-60 years of age, whereas prostatitis, PIN and adenocarcinoma usually present in the age group of 61-70 years. Similar findings were seen by Jasani et al, [5] whereas Goswami et al [6] had proposed that benign lesions had a mean age of presentation of $68.1 \pm 8.1$ and malignant lesions had a mean age of presentation of 70.3 \pm 5.6 .

In our study, $48 \%$ had PSA levels above10ng/ml which was comparable to a study done by D P Murthy et al, [9] Cavit et al [10] and Goswami et al [6] reported PSA levels of $4.01 \mathrm{to} 10 \mathrm{ng} / \mathrm{ml}$ in majority of their cases. $6 \%$ of the cases had a PSA value above $100 \mathrm{ng} / \mathrm{ml}$, which was comparable to the study done by D P Murthy et al[9] in which $11 \%$ of the cases had a PSA value above this level.

While comparing the serum PSA levels and histo-pathological diagnosis in our study, majority of the cases of BPH had a PSA levels within $10 \mathrm{ng} / \mathrm{ml}$. All the malignant lesions had values above $20 \mathrm{ng} / \mathrm{ml}$, six of them had above $100 \mathrm{ng} / \mathrm{ml}$ among which one case had a value of $1525 \mathrm{ng} / \mathrm{ml}$. All cases with PSA above $100 \mathrm{ng} / \mathrm{ml}$ were malignant, none were benign on biopsy. In cases of PIN there was no particular range of PSA in which the cases were predominantly distributed

Most of the cases of BPH had serum PSA levels less than $10 \mathrm{ng} / \mathrm{ml}$ with $45 \%$ cases having between $4-10 \mathrm{ng} / \mathrm{ml}$ and the rest of the cases within the normal value of $4 \mathrm{ng} / \mathrm{ml}$. In studies done by Jasani et al [5], Lakhey $\mathrm{M}$ et al [4] and Kshitij et al [11] majority of the cases had PSA within the normal range. In studies done by Goswami et al [5] and Ishtiaq Ali et al [12] majority of the cases had PSA in the range of $4-10 \mathrm{ng} / \mathrm{ml}$ which were comparable to our study.

It was also observed that majority of the cases with acute prostatitis had PSA level above 10ng/ml in contrast to the study done by Yamamoto et al [13] in which PSA levels was equally distributed in different ranges. Most of the cases of chronic prostatitis had PSA in the range of 4.01 to $10 \mathrm{ng} / \mathrm{ml}$ in contrast to Yamamoto in which PSA levels was within the normal range. Jasani et al [5] had 5 cases of chronic prostatitis with PSA value within 10ng/ml.

Prostate intraepithelial neoplasm (PIN) being a premalignant condition does not cause significant elevation in the serum PSA. In the present study, PSA levels in cases of PIN had a minimum of $0.03 \mathrm{ng} / \mathrm{ml}$ and a maximum of $58.3 \mathrm{ng} / \mathrm{ml}$, median value being $14 \mathrm{ng} / \mathrm{ml}$. In a study done by Brawer et al [14] the minimum, maximum and median values of PSA in a study of 19 cases of PIN were $0.2 \mathrm{ng} / \mathrm{ml}, 19.2 \mathrm{ng} / \mathrm{ml}$ and $4 \mathrm{ng} / \mathrm{ml}$ respectively. Porter J R and Brawer M K [15] reported 25 cases of PIN in whom PSA levels were in the range of 0.2 to $19.2 \mathrm{ng} / \mathrm{ml}$ with a mean PSA value of $7.8 \mathrm{ng} / \mathrm{ml}$, they also compared the PSA levels in benign and malignant prostatic lesions to conclude that the levels in PIN were intermediate between these two groups.

The median PSA level in case of low grade PIN was $14.6 \mathrm{ng} / \mathrm{ml}$. All the cases of low grade PIN were associated with $\mathrm{BPH}$. The maximum value was $58.3 \mathrm{ng} / \mathrm{ml}$ which can be attributed to the associated BPH and prostatitis. Osman Nuri et 


\section{Research Article}

al [16] had reported the average PSA value in cases with low grade PIN was $11.32 \pm 6.71$. In our study 10 of the total 15 cases of low grade PIN had PSA values above 10ng/ml. The higher levels of PSA in low grade PIN can be attributed to the associated BPH and prostatitis as is mentioned in other studies.

In cases of high grade PIN the minimum, maximum and median values of PSA were $2.8 \mathrm{ng} / \mathrm{ml}, 23.8 \mathrm{ng} / \mathrm{ml}$ and $15.9 \mathrm{ng} / \mathrm{ml}$ respectively. Out of the total eight cases, five cases had PSA levels between $10 \mathrm{ng} / \mathrm{ml}$ to $20 \mathrm{ng} / \mathrm{ml}$. In his study, Benjamin Kulovac et al [17] concluded that the serum PSA level for high grade PIN was intermediate between BPH and carcinoma prostate. Also according to the study done by Yang J Y et al [18] the mean PSA level in 21 cases of isolated high grade PIN was $1.9 \mathrm{ng} / \mathrm{ml}$ with a range of $0.7 \mathrm{ng} / \mathrm{ml}$ to $8 \mathrm{ng} / \mathrm{ml}$. The study concluded that high grade PIN does not cause significant elevation of serum PSA therefore, adenocarcinoma of prostate should be ruled out as a source of elevated PSA in patients with high PSA and isolated high grade PIN on needle biopsy.
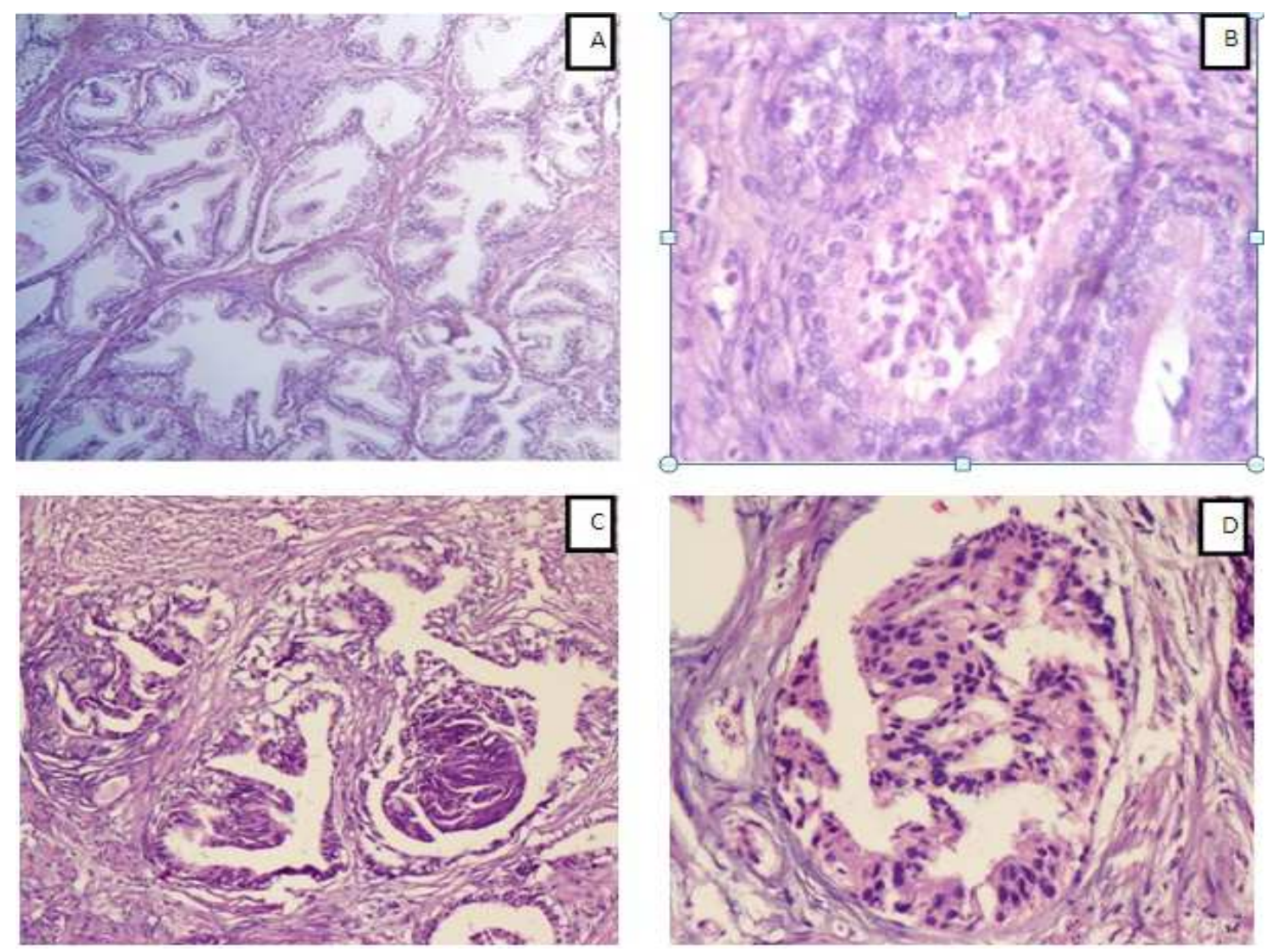
A: X200, H\&E Benign prostatic hyperplasia. B: X400, H\&E Acute Prostatitis, C: X200 H\&E, Low grade PIN, D: X400, High grade PIN.

In our study, all the 27 cases of carcinoma prostate had PSA level above 10ng/ml. This is comparable to other studies in which majority of the cases of adenocarcinoma prostate had PSA above 10ng/ml, except for a study done by Goswami et al,[6] most of the studies in the literature had very few cases of carcinoma with PSA values within the normal reference range. Surprisingly in a study done by D P Murthy et al [9] 28.8\% of the total 45 cases had PSA value within the normal range.

The minimum, maximum and median values of PSA in cases of carcinoma were $10 \mathrm{ng} / \mathrm{ml}, 1525 \mathrm{ng} / \mathrm{ml} \mathrm{and} 81 \mathrm{ng} / \mathrm{ml}$ respectively. Also in a study done by W Obara et al [3] the minimum, maximum and median values in carcinoma prostate were $24.53 \mathrm{ng} / \mathrm{ml}, 333 \mathrm{ng} / \mathrm{ml}$ and $58.3 \mathrm{ng} / \mathrm{ml}$ respectively. In another study done by DP Murthy et al [9] the PSA levels in prostatic malignancy had a range of $3.9 \mathrm{ng} / \mathrm{ml}$ to $629.5 \mathrm{ng} / \mathrm{ml}$.

We have also assessed the sensitivity and specificity of different cut off points of PSA in detecting malignancy. At a cut off value of $19.5 \mathrm{ng} / \mathrm{ml}$ the sensitivity, specificity, positive predictive value and negative predictive value were 96.3 , 
Research Article

86.18, 60.47 and 99.07 respectively. In a study done by W obara et al [3] the sensitivity of PSA for carcinoma prostate at cut off point of $4 \mathrm{ng} / \mathrm{ml}$ and $10 \mathrm{ng} / \mathrm{ml}$ were $89.8 \%$ and $83.7 \%$ respectively, specificity was $37 \%$ at $4 \mathrm{ng} / \mathrm{ml}$ and $66 \%$ at $10 \mathrm{ng} / \mathrm{ml}$. In the same study the positive predictive value at $4 \mathrm{ng} / \mathrm{ml}$ and $10 \mathrm{ng} / \mathrm{ml}$ were $49 \%$ and $63 \%$ respectively. The cut-off point of $19.5 \mathrm{ng} / \mathrm{ml}$ in our study is much higher compared to other studies.

While PSA level measurement is currently the best single test for early prostate cancer detection, digital rectal examination can also identify men with the disease. Studies done by Bretton et al [19] and Catalona et al [20] have suggested that combining both tests improves the overall rate of prostate cancer detection when compared to either test alone. In our study all the cases with abnormal digital rectal examination had abnormal PSA value and $79.4 \%$ of the cases had malignant lesion on biopsy.

\section{Conclusion}

Prostate specific antigen (PSA) is specific for the organ prostate, this biochemical marker should be used in conjunction with digital rectal examination and biopsy (Needle or trans-urethral resection specimen) if required, to identify the benign or premalignant condition (PIN). We, in this study show that PSA $>10 \mathrm{ng} / \mathrm{ml}$ is seen in PIN and adenocarcinoma. The cut off value of $19.5 \mathrm{ng} / \mathrm{ml}$ of PSA is most sensitive and specific for the detection of malignant lesion in the prostate. In Benign prostatic lesion, PSA level is in between 0 to $4.0 \mathrm{ng} / \mathrm{ml}$. Present study shows that DRE and PSA are the most useful front line methods for assessing and individual's risk of prostate cancer. In addition to elevated level of more than $4.0 \mathrm{ng} / \mathrm{ml}$ and abnormal DRE with TURP biopsy is most useful and accurate diagnostic method for prostatic lesions.

Funding: Nil, Conflict of interest: None initiated, Permission from IRB: Yes

\section{Reference}

1.Macaluso PM. Epidemiology, prevention and screening for prostate cancer. Eur Urol. 1996; 29(2): $49-53$.

2. Brawer MK. Screening and early detection of prostate cancer will decrease morbidity and mortality from prostate cancer. The Augment for Eur Urol. 1996; 29(2):19-23.

3. A. Amayo and W.Obara. Serum prostate specific antigen levels in men with benign prostatic hyperplasia and cancer of prostate. East African Medical Journal 2004; 81(1):22-25.

4. Lakhey. M, Ghimire. R,Shrestha. R, Bhatta A D. Correlation of serum free prostate- specific antigen level with histological findings in patients with prostatic disease. Kathmandu University Medical Journal 2010; 8(30):158-163.
5. Jasmin H Jasani, Himani B. Patel, Bijol Gheewala, Hetal V. Vaishnani, Kaushik Bhuva. Diagnostic utility of prostate specific antigen for detection of prostatic lesions. International Journal of biomedical and advance research 2012; 3(4):268 - 272.

6. Goswami A, Rupala G et al. Serum PSA levels in prostatic lesions with histopathological correlation in Gujarat. NJIRM 2011; 2(4):33-38.

7. Lowe FC et al. Risk factors for disease progression in patients with lower urinary tract symptoms/benign prostatic hyperplasia (LUTS/BPH): a systematic analysis of expert opinion. Prostate Cancer and Prostatic Diseases 2005; 8:206-209. doi:10.1038/sj. pcan.4500806

8. Jimenez-Cruz F. Identifying patients with lower urinary tract symptoms/benign prostatic hyperplasia (LUTS/BPH) at risk for progression. Eur Urol Suppl 2003; 2 : 6-12.

9. DP Murthy, U Ray, J Morewaya, SK Sengupta. A study of the correlation of prostatic pathology and serum prostate specific antigen levels; A perspective from Papua New Guinea. PNGMedJ.1998;41(2):59-64.

10. Cavit C, Tanner $\mathrm{C}$ et al. Correlation of serum free/total prostate specific antigen (PSA) levels with histological findings in the Turkish men with prostatic disease after the first biopsy. Scholarly Journal of Medicine 2011; 1(1): 5-11.

11. Kshitij A. jyoti sapre, A.S.Agnihotri et al: utility of prostate specific antigen in different prostatic lesion: Pathology and laboratory medicine; Jun 2011;(1):18-23.

12. Khan I A et al. Carcinoma of prostate in clinically benign enlarged gland. J Ayub med coll Abottabad 2008; 20(2): 90-92. 


\section{Research Article}

13. Yamamoto M, Hibi H, Miyake K. Prostate specific antigen levels in acute and chronic bacterial prostatitis. Acta Urol.Jpn 1993; 39:445 - 449.

14. Brawer MK, Lange PH. Prostate-Specific Antigen and Premalignant Change: Implications for Early Detection. CA: A Cancer journal for clinicians 1989; 39(6):361 - 375 .

15. Brawer MK, Porter JR.Prostatic intraepithelial neoplasia and prostate specific Antigen. World J Urol 1993; 11(4):196 - 200.

16. Abukult O N, Duman I. Prostatic intraepithelial neoplasm: Retrospective results of Clinical, histopathological approaches. Journal of Cell and Molecular Biology 2004; 3:45 - 50 .

17. Obralic N, Kulovac B. High grade intraepithelial neoplasia of prostate is associated with values of prostate specific antigen related parameters intermediate between prostate cancer and normal levels. Bosn J Basic Med Sci 2011; 11(4): 223-227.

18. KIM H. L, Yang X. Prevalence of High-Grade Prostatic Intraepithelial Neoplasia and its relationship to serum prostate specific antigen. International Braz $\mathbf{J}$ Urol 2002; 28(5):413 - 417.

19. Bretton, P.R. Prostate-specific antigen and digital rectal examination in screening for prostate cancer: a community-based study. South Med J 1994; 87(7): $720-723$.

20. Richie J.P, Catalona W. Effect of patient age on early detection of prostate cancer with serum prostatespecific antigen and digital rectal examination. Urology1993; 42(4):365-74.

\section{How to cite this article?}

Shetty P, Singh B.M.K, Shetty T, Bishnu A. Correlation of prostate specific antigen level with histopathological findings in patients with prostatic disease.Trop J Path Micro 2016;2(3):152-158.doi:10.17511/jopm.2016.i03.12 